\title{
MEDIA ONLINE DAN PEMBERITAAN TERORISME (ANALISIS ISI BERITA PENEMBAKAN DI MASJID SELANDIA BARU PADA MEDIA ONLINE DETIK.COM)
}

\author{
Ade Irfan Abdurahman, S.Kom.I, M.Si \\ Email: airfan@unis.ac.id \\ Jurusan Ilmu Komunikasi, Fakultas Ilmu Politik dan Ilmu Sosial \\ Jl. Maulana Yusuf No.10, Babakan, Kec. Tangerang, Kota Tangerang, Banten 15118. 021-5527061 /
}

5527063

\begin{abstract}
ABSTRAK
Media beberapa kali menjadi sorotan karena mengorbankan etika demi mengejar kecepatan. Padahal, dalam konteks pemberitaan terorisme, mengesampingkan etika berpotensi turut berperan dalam penyebaran teror di masyarakat. Dengan menggunakan analisis isi, penelitian ini dilakukan untuk mendeskripsikan bagaimana media online memberitakan peristiwa teror di Selandia Baru. Dengan mengkaji 54 berita yang tayang di hari pertama terjadinya teror penelitian ini menguji ada atau tidaknya pelanggaran pada tujuh kategori Pedoman Peliputan Terorisme dalam berita yang dikaji. Tujuh kategori tersebut antara lain; Melakukan promosi dan legitimasi terhadap tindakan terorisme, stigma yang tidak relevan, tidak mengimplementasikan asas praduga tidak bersalah, mengungkap rincian modus operandi, menyiarkan foto atau adegan korban terorisme, memilih pengamat yang tidak memiliki kredibilitas, kabapilitas dan kompetensi, dan tidak melakukan check dan recheck. Hasilnya, secara umum peneliti menyimpulkan bahwa media online detik.com patuh terhadap Pedoman Pemberitaan Terorisme Dewan Pers karena tingkat pelanggarannya bernilai dibawah lima puluh persen.
\end{abstract}

\section{ABSTRACT}

Media get the spotlight because of sacrificing ethics for the speed of reportage. In fact, in reporting terrorism, ignoring ethics has the potential damage which make the media play a role in spreading terror through societies. Using content analysis, this study aims to describe how online media detik.com reported terror in New Zealand. By examining 54 news that published in the first day of terror, this study examined the presence or absence of violations in the seven categories of "Terrorism News Guidelines". The seven categories are; Promoting and legitimating terrorism, irrelevant stigma, not implementing the presumption of innocence, revealing details of the terror operation, broadcasting photos or scenes of victims, choosing observers who do not have credibility, capability and competence, and do not check and recheck the news. As a result, the researcher concluded that online media detik.com complies with the Press Council's Terrorism News Guidelines because the violation rate is below fifty percent. 


\section{PENDAHULUAN}

Kita semua sepakat bahwa terorisme adalah kejahatan luar biasa yang melanggar Hak Asasi Manusia (HAM). Karena itu dalam penangananya perlu kerjasama berbagai elemen, termasuk media massa untuk turut meredam aksi terorisme, bukan malah menyebarkan teror dan memperburuk keadaan.

Media massa menulis berita terorisme untuk kepentingan publik. Karena itu, media massa perlu berhati-hati dalam pemberitaan teror, fakta harus akurat dan dilakukan check dan recheck, tidak hanya, itu media sebaiknya memilih informasi apa yang patut dan tidak patut untuk disampaikan kepada khalayak.

Jika salah dalam mengemas, berita terorisme justru dapat menguntungkan bagi teroris. Manuel R. Torres Soriano mengutip Marshall McLuhan menjelaskan bahwa "without communication terrorism would not exist"(Soriano, 2008). Ungkapan ini menjelaskan bahwa komunikasi dimana media menjadi medium penyampaian pesan memiliki peran besar dalam menyebarkan teror. Teroris telah menemukan manfaat besar dari media massa untuk mendapatkan perhatian publik.

Menurut Briggitee Nacos (dalam Soriano, 2008) aksi terorisme biasanya bertujuan untuk mendapatkan 3 hal, diantaranya: to get attention, to gain recognition dan even in order to obtain a certain degree of respect and legitimacy. (untuk mendapatkan perhatian, untuk mendapatkan pengakuan dan bahkan untuk mendapat rasa hormat dan legitimasi)

Hubungan antara teroris dan media juga ditegaskan oleh Giessman (dalam Prajarto, 2004) antara lain:

1. Kelompok teroris mencari perhatian media untuk sebisa mungkin mendapatkan perhatian publik

2. Kelompok teroris kerap mengusung sensasi yang mereka manipulasi untuk tujuan propaganda

3. Media massa menerima bentuk symbiosis demi mendapatkan gambar-gambar yang menarik dan berita-berita mengejutkan serta menjadi leading terhadap kompetitornya.

Hubungan simbiosis seperti ini yang dikhawatirkan. Media seharusnya mampu memilah dan membatasi sebaran berita yang berpotensi menyebarkan rasa takut dan teror di masyarakat, bukan secara tidak sadar justru menjadi alat propaganda teroris. Karena itu, media perlu sangat berhati-hati apalagi pemberitaan yang berkaitan tentang isu terorisme kerap menjadi isu popular di media massa. 
Di Indonesia, Pemberitaan tentang terorisme biasa mendapatkan tempat eklusif di media massa. Para pewarta berlomba untuk menjadi yang tercepat dan eklusif dalam memberikan informasi ke masyarakat. Sayangnya, perlombaan menjadi yang tercepat dan paling ekslusif ini terkadang menimbulkan pelanggaran etika jurnalistik.

Di tahun 2016, Komisi Penyiaran Indonesia (KPI) Pusat menjatuhkan sanksi teguran tertulis kepada delapan lembaga penyiaran terkait pemberitaan tragedi Sarinah, yaitu Metro TV, TVRI, NET TV, Trans 7, INews, Indosiar, TV One, dan Radio Elshinta. Delapan media tersebut melanggar Pedoman Perilaku Penyiaran dan Standar Program Siaran (P3 \& SPS) tentang akurasi berita dan larangan menampilkan gambar mayat. (republika.co.id: 2016)

Berita detik.com (2017) pernah dipertanyakan publik, karena dinilai terlalu cepat dalam memberitakan teror bom di terminal kampung Melayu. Berita detik.com tentang kasus terror di terminal kampung melayu memang naik pukul 21.05 atau tepat 5 menit pasca kejadian bom pertama pukul 21.00. Dalam klarifikasinya, detik.com menjelaskan bahwa naiknya berita bom kampung melayu sudah melalui proses verifikasi. Bagi detikcom, penting untuk secepat mungkin menaikkan berita bom kampung melayu.

"Prinsip "Mengapa harus menunggu besok? Detik ini juga!" kami pegang erat-erat. "Kamu itu wartawan detikcom, bukan jamcom, bukan hariancom. Cepat kalau bikin berita." Ujaran-ujaran seperti itu sudah mendarah daging dan menjadi sistem di detikcom dalam membuat berita secara cepat. Maka misalnya, begitu detikcom mendapat informasi ada bom di Kampung Melayu, kami langsung bergerak cepat. Adalah seorang warga yang sedang melintas di lokasi memberi informasi kepada detikcom lewat aplikasi percakapan."

Kecepatan memperoleh dan menyebarkan berita kepada khalayak memang menjadi tujuan Media. Hanya saja, andai tidak berhati-hati dan tidak selektif dalam memberikan informasi terhadap khalayak. Media bisa saja menjadi sarana penyambung teror. Hal itu yang peneliti khawatirkan pasca teror di Selandia Baru.

Berita penembakkan di Selandia baru dengan cepat sampai dan diinfokan ke khalayak di Indonesia melalui kanal media online lokal. Perkembangan teknologi informasi membuat penyebaran informasi menjadi borderless. Kejadian di Selandia 
Baru tidak hanya menjadi teror bagi warganya, namun juga menjadi teror bagi masyarakat dunia. Informasi didapatkan dengan mudah melalui media konvensional ataupun media online.

Adapun dalam penelitian ini, peneliti memberikan fokus terhadap media online. Media online dipilih menjadi fokus, karena memiliki beberapa kelebihan seperti; Cepat dan Segera dalam menyampaikan informasi, nonlinaritiy atau Multiple pagination, memungkinkan sarana multimedia, memiliki ruang tak terbatas dan beritanya terarsipkan dengan baik. Dengan beberapa kelebihan yang dimilikinya, media online bisa saja menjadi sarana paling efektif dalam konteks turut menyebarkan teror seperti yang diinginkan oleh teroris.

Karena itu, dengan menggunakan analisis isi kuantitatif terhadap detik.com peneliti berkeinginan untuk mengetahui relasi antara media dan terorisme, serta secara mendalam menemukan apakah berita detik.com tentang teror di selandia baru mengikuti pedoman peliputan terorisme yang dibuat dewan pers atau justru terdapat pelanggaran-pelanggaran.

\section{MEDIA ONLINE \& TERORISME}

Berdasarkan pada publikasi Aliansi Jurnalis Independen (AJI) Indonesia, berjudul Media Online: Pembaca, Laba, dan Etika (Margianto \& Syaefullah, 2012)
Media online di Indonesia mulai berkembang saat layanan jasa internet komersil hadir di Indonesia tahun 1994. Tercatat ada beberapa surat kabar yang memindahkan konten edisi cetaknya ke internet seperti Republika yang membuat www.republika.co.id (17 Agustus 1994), Majalah tempo dengan tempointeraktif (1996), Bisnis Indonesia situsnya lahir pada 2 September 1996, Harian waspada di sumatera Utara dengan www.waspada.co.id (11 Juli 1997), dan menyusul Kompas yang mendirikan www.kompas.com (22 Agustus 1997).

Kemudian, pada 9 Juli 1998 detik.com mengunggah kontennya untuk pertama kali. Detik.com merupakan satusatunya pelopor media online otonom yang tidak media cetak yang mengindukinya. Hadirnya detik.com merubah situasi. Detik.com mengenalkan jenis berita baru: ringkas to the point. Mementingkan kecepatan, berita detik.com tidak selalu dengan unsur $5 \mathrm{~W}+1 \mathrm{H}$ layaknya pakem jurnalistik, detik.com mengenalkan jenis running news penyajian berita serial seperti cara breaking news stasiun berita CNN. (Margianto \& Syaefullah, 2012)

Saat ini, media online berkembang pesat dan mulai menggeser media konvensional. Merangkum tulisan James C. Foust (2005) dan Mike Ward (2002: 2126) kelebihan jurnalisme online 
dibandingkan dengan jurnalisme konvensional antara lain:

1. Cepat dan Segera. Media online memungkinkan jurnalis untuk menyampaikan informasi secapat mungkin kepada khalayak

2. Nonlinaritiy atau Multiple pagination. Media online memungkinkan berita dapat berdiri sendiri, namun juga memungkinkan untuk terkait satu sama lain.

3. Kontrol Khalayak dan Interaksi. Khalayak media online memiliki control lebih dalam memilih berita, tidak hanya itu, banyak media online yang juga mengijinkan khalayak untuk berinteraksi lewat komentar.

4. Multimedia. Media online memungkinkan format penyajian berita dengan gabungan teks, gambar, audio, video dan grafis dalam satu sajian berita.

5. Ruang tak terbatas dan Terarsipkan. Media online memiliki ruang tak terbatas untuk mengarsipkan berita, sehingga khalayak dapat mencari dan mengakses berita-berita terdahulu meski sudah lama terjadi.

Namun, dengan beberapa kelebihan media online tersebut, menyisakan satu celah serius bagi media online yaitu masalah akurasi. Kecepatan yang menjadi kelebihan utama media online justru berdampak pada minimnya verifikasi.

Menurut ketua umum AJI, Eko Maryadi dalam pengantar publikasi berjudul Media Online: Pembaca, Laba, dan Etika (Margianto \& Syaefullah, 2012) kerapkali atas nama kecepatan, pageview, dan pertumbuhan bisnis, media online malah terjerambab menyampaikan informasi yang belum final terverifikasi kepada masyarakat luas sehingga terkadang menimbulkan mis-persepsi dan mis-interpretasi fakta.

Karenanya, andai media online terjerembab pada berita yang minim verifikasi atau salah melakukan analisa. Maka sangat mungkin untuk masuk ke dalam jebakan pemanfaatan media oleh teroris. Menyikapi kemungkinan pemanfaatan media oleh teroris, Dewan Pers melalui peraturan no Nomor: 01/Peraturan-DP/IV/2015 tentang Pedoman Peliputan Terorisme mengatur 13 kategori yang menjadi acuan bagi wartawan dalam meliput dan menulis berita teroris, antara lain:

Tabel.1

13 Kategori Pedoman Peliputan Teror

\begin{tabular}{|l|l|l|l|}
\hline NO & \multicolumn{1}{|c|}{ Kategori } & No & \multicolumn{1}{c|}{ Kategori } \\
\hline 1 & $\begin{array}{l}\text { Menempatkan } \\
\text { keselamatan jiwa } \\
\text { sebagai prioritas di }\end{array}$ & 7 & $\begin{array}{l}\text { Menghindari } \\
\text { mengungkap rincian } \\
\text { modus operandi tindak }\end{array}$ \\
\hline
\end{tabular}




\begin{tabular}{|c|c|c|c|}
\hline & $\begin{array}{l}\text { atas kepentingan } \\
\text { berita. }\end{array}$ & & pidana terorisme \\
\hline 2 & $\begin{array}{l}\text { Menempatkan } \\
\text { kepentingan publik di } \\
\text { atas kepentingan } \\
\text { jurnalistik }\end{array}$ & 8 & $\begin{array}{l}\text { Tidak menyiarkan foto } \\
\text { atau adegan korban } \\
\text { terorisme yang } \\
\text { berpotensi } \\
\text { menimbulkan kengerian } \\
\text { dan pengalaman } \\
\text { traumatik. }\end{array}$ \\
\hline 3 & $\begin{array}{l}\text { Menghindari } \\
\text { pemberitaan yang } \\
\text { berpotensi } \\
\text { mempromosikan dan } \\
\text { memberikan legitimasi } \\
\text { maupun glorifikasi } \\
\text { terhadap tindakan } \\
\text { terorisme }\end{array}$ & 9 & $\begin{array}{l}\text { Menghindari peliputan } \\
\text { keluarga terduga teroris } \\
\text { untuk mencegah } \\
\text { diskriminasi dan } \\
\text { pengucilan oleh } \\
\text { masyarakat, }\end{array}$ \\
\hline 4 & $\begin{array}{l}\text { Tidak melaporkan } \\
\text { secara terinci/ detail } \\
\text { peristiwa pengepungan } \\
\text { dan upaya aparat } \\
\text { dalam melumpuhkan } \\
\text { para tersangka } \\
\text { terorisme }\end{array}$ & 10 & $\begin{array}{l}\text { Pertanyaan dan } \\
\text { pendekatan terhadap } \\
\text { keluarga pelaku atau } \\
\text { keluarga korban } \\
\text { dilakukan secara } \\
\text { simpatik dan bijak }\end{array}$ \\
\hline 5 & $\begin{array}{l}\text { Tidak memberikan } \\
\text { atribusi, gambaran, } \\
\text { atau stigma yang tidak } \\
\text { relevan }\end{array}$ & 11 & $\begin{array}{l}\text { Memilih pengamat } \\
\text { yang memiliki } \\
\text { kredibilitas, kapabilitas } \\
\text { dan kompetensi }\end{array}$ \\
\hline 6 & $\begin{array}{l}\text { Menjunjung asas } \\
\text { praduga tidak bersalah } \\
\text { (presumption of } \\
\text { innocense) }\end{array}$ & 12 & $\begin{array}{l}\text { Berpikir ulang untuk } \\
\text { meliput aksi terorisme }\end{array}$ \\
\hline & & 13 & $\begin{array}{l}\text { Wartawan wajib selalu } \\
\text { melakukan check dan } \\
\text { rechek terhadap semua } \\
\text { berita }\end{array}$ \\
\hline
\end{tabular}

Dalam konteks terorisme di Selandia

Baru. Media online bisa menjadi sarana paling efektif dalam rangka turut menyebarkan teror. Untuk menguji hal tersebut, peneliti menggunakan analisis isi guna melihat ada atau tidaknya isi berita detik.com tentang teror di selandia baru yang melanggar kode etik dewan pers tentang Pedoman Peliputan Terorisme. Jika terdapat pelanggaran, peneliti kemudian akan mendiskusikan apakah temuan tersebut berkaitan dengan potensi pemanfaatan media untuk menyebarkan teror atau tidak.

\section{METODE PENELITIAN}

Penelitian ini menggunakan metode analisis isi kuantitatif (quantitative content analysis). Analisis Isi kuantitatif menurut Eriyanto (2013) adalah analisis yang digunakan untuk mengukur aspek-aspek tertentu dari isi secara kuantitatif. Karena itu dalam konteks analisis isi media online ini, peneliti akan menghitung secara akurat aspek atau dimensi teks dari isi media online yang berkaitan dengan Kategori Pedoman Peliputan Teror secara kuantitatif di detik.com. Tujuannya adalah untuk dapat mendeskripsikan bagaimana detik.com memberitakan kasus penembakan di masjid New Zealand 2019. Menemukan ada atau tidaknya pelanggaran Pedoman Peliputan Teror, dan mendeskripsikan apakah temuan ini berpotensi menjadikan detik.com sebagai media online yang turut menyebar teror atau tidak.

Media Online detik.com dipilih karena detik.com merupakan salah satu pelopor media online di Indonesia. Sebagai pelopor dan sudah berumur 20 tahun, tentu detik.com memiliki pengalaman yang cukup dalam proses 
penyampaian berita. Selain itu hingga bulan desember 2019, berdasarkan alexa rank detik.com berada di 5 besar top site di Indonesia dan ada dalam 3 besar top site berita di Indonesia.

\section{Gambar.1}

Top Site in Indonesia

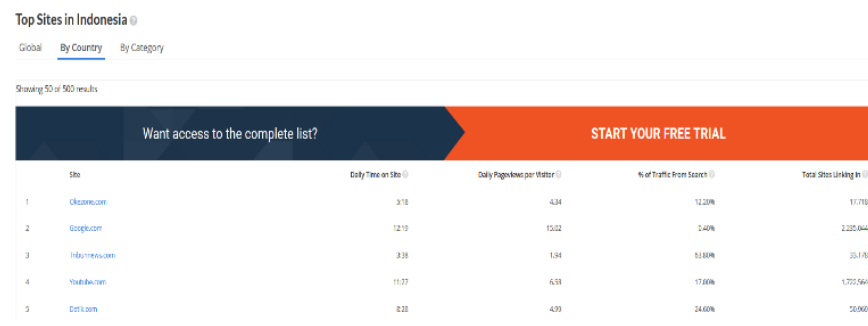

Desain analisis yang dipakai adalah analisis deksriptif. Adapun Teknik penentuan sampel dalam penelitian ini dilakukan secara purposif atau ditentukan secara sengaja berdasarkan pertimbangan tertentu. Dalam penelitian ini peneliti memilih berita detik.com yang di naikkan di hari terjadinya teror. Karena hari saat terjadinya teror merupakan hari yang paling rawan, karena keinginan mengejar kecepatan berita media online berpotensi melanggar kode etik Pedoman Peliputan Terorisme Dewan Pers.

Dari 13 kategori Pedoman Peliputan Terorisme. Peneliti hanya menguji 9 Kategori yang menurut peneliti relevan dengan pemberitaan teror di Seladia Baru. Adapun kategori yang peneliti ambil dari antara lain: Promosi, Legitimasi dan
Glorifikasi, Stigma Tidak Relevan, Preasumption of Innocent, Rincian Modus Operandi, dan Menampilkan Foto atau Video Korban.

Tabel. 2

7 Kategori Pedoman Peliputan Teror yang di uji dalam penelitian ini

\begin{tabular}{|c|c|c|}
\hline NO & Kategori & No \\
\hline 1 & $\begin{array}{l}\text { Menghindari pemberitaan yang } \\
\text { berpotensi mempromosikan dan } \\
\text { memberikan legitimasi maupun } \\
\text { glorifikasi terhadap tindakan terorisme }\end{array}$ & $\begin{array}{l}\text { 1. Ya } \\
\text { 2. Tidak }\end{array}$ \\
\hline 2 & $\begin{array}{l}\text { memberikan atribusi, gambaran, atau } \\
\text { stigma yang tidak relevan }\end{array}$ & $\begin{array}{l}\text { 1. } \mathrm{Ya} \\
\text { 2. } \text { Tidak }\end{array}$ \\
\hline 3 & $\begin{array}{l}\text { Tidak Menjunjung asas praduga tidak } \\
\text { bersalah (presumption of innocense) }\end{array}$ & $\begin{array}{ll}\text { 1. } & \text { Ya } \\
\text { 2. } & \text { Tidak }\end{array}$ \\
\hline 4 & $\begin{array}{l}\text { Mengungkap rincian modus operandi } \\
\text { tindak pidana terorisme }\end{array}$ & $\begin{array}{ll}\text { 1. } & \text { Ya } \\
\text { 2. } & \text { Tidak }\end{array}$ \\
\hline 5 & $\begin{array}{l}\text { Menyiarkan foto atau adegan korban } \\
\text { terorisme yang berpotensi menimbulkan } \\
\text { kengerian dan pengalaman traumatik. }\end{array}$ & $\begin{array}{l}\text { 1. Ya } \\
\text { 2. Tidak }\end{array}$ \\
\hline 6 & $\begin{array}{l}\text { Memilih pengamat yang memiliki } \\
\text { kredibilitas, kapabilitas dan kompetensi }\end{array}$ & $\begin{array}{ll}\text { 1. } & \text { Ya } \\
\text { 2. } & \text { Tidak }\end{array}$ \\
\hline 7 & $\begin{array}{l}\text { Tidak melakukan check dan rechek } \\
\text { terhadap semua berita }\end{array}$ & $\begin{array}{ll}\text { 1. } & \text { Ya } \\
\text { 2. } & \text { Tidak }\end{array}$ \\
\hline
\end{tabular}

\section{HASIL DAN PEMBAHASAN}

Penelitian ini mengkaji berita tentang kasus terorisme di Selandia Baru pada Media Online detik.com. Jika dilihat dari sumber berita, dari 54 rata-rata berita yang diangkat oleh detik.com di hari pertama terjadinya teror berasal dari media $\operatorname{asing}(42,6 \%)$. 
Tabel.3

Sumber Berita

\begin{tabular}{|c|c|c|c|c|c|}
\hline \multicolumn{2}{|c|}{} & Frequency & Percent & $\begin{array}{c}\text { Valid } \\
\text { Percent }\end{array}$ & $\begin{array}{c}\text { Cumulative } \\
\text { Percent }\end{array}$ \\
\hline Valid & $\begin{array}{c}\text { Keterangan } \\
\text { Juru Bicara }\end{array}$ & 4 & 7,4 & 7,4 & 7,4 \\
\cline { 2 - 6 } & $\begin{array}{c}\text { Keterangan } \\
\text { Pers }\end{array}$ & 9 & 16,7 & 16,7 & 24,1 \\
\cline { 2 - 6 } & $\begin{array}{c}\text { Liputan } \\
\text { Wartawan } \\
\text { Surat Kabar }\end{array}$ & 18 & 33,3 & 33,3 & 57,4 \\
\cline { 2 - 6 } & $\begin{array}{c}\text { Media } \\
\text { Asing }\end{array}$ & 23 & 42,6 & 42,6 & 100,0 \\
\cline { 2 - 6 } & Total & 54 & 100,0 & 100,0 & \\
\hline
\end{tabular}

Adapun Media Asing yang dikutip oleh detik.com antara lain. ABC Australia, AFP, BBC World, Channel News Asia, CNN, news.com.au, Reuteurs, Stuff.Co.Nz, Telegraph, dan New Zealand Herald. Sedangkan sisanya berita detik.com berasal dari Keterangan Juru Bicara $(7,4)$, Keterangan Pers $(16,7)$ dan Liputan wartawan surat kabar $(33,3)$.

Setelah proses analisis data secara kuantitatif terhadap 7 kategori ditemukan beberapa fakta berikut ini:

\section{Promosi, Legitimasi dan Glorifikasi}

Berdasarkan pada Pedoman Peliputan Terorisme wartawan harus menghindari pemberitaan yang berpotensi mempromosikan dan memberikan legitimasi maupun glorifikasi terhadap tindakan terorisme maupun pelaku terorisme. (Poin 3
Pedoman Peliputan Terorisme).

Karena itu, ada tiga hal yang perlu diperhatikan oleh media dalam peliputan terirosme.

1. Media dilarang untuk terlibat dalam mempropagandakan atau memperkenalkan kegiatan teror. (Promosi).

2. Media dilarang untuk terlibat dalam mengesahkan atau membenarkan perbuatan teror .(Legitimasi)

3. Media dilarang untuk terlibat meluhurkan dan memuliakan aksi terorisme. (Glorifikasi)

Dalam satu hari pemberitaan detik.com di hari pertama peristiwa teror dari 54 berita yang dinaikkan ada 2 berita $(3,7 \%)$ yang menunjukkan bentuk legitimasi terhadap tindakan teror di Selandia Baru.

Tabel. 4

Legitimasi

\begin{tabular}{|ll|r|r|r|r|}
\hline & Frequency & Percent & Percent & $\begin{array}{c}\text { Cumulative } \\
\text { Percent }\end{array}$ \\
\hline Valid & Ada & 2 & 3,7 & 3,7 & 3,7 \\
& Tidak Ada & 52 & 96,3 & 96,3 & 100,0 \\
& Total & 54 & 100,0 & 100,0 & \\
\hline
\end{tabular}

Bentuk Legitimasi yang diangkat berkaitan dengan adanya kecaman terhadap Seorang Senator Australia bernama Fraser Anning. Mengutip Telegraph, detikcom menuliskan legitimasi dan glorifikasi Fraser Anning terhadap Aksi Teror. Anning dalam tulisannya via twitter justru menyalahkan 
kaum muslim fanatik yang bermigrasi ke Selandia Baru.

Meski dalam keseluruhan beritanya detik.com ingin melakukan framing bahwa pendapat Fraser Anning ditentang dan mendapat kecaman dari berbagai pihak. Namun tetap saja, secara tidak langsung detik.com telah memberikan ruang bagi tersebarnya opini Fraser Anning tentang peristiwa teror di Selandia Baru. Bisa saja orang-orang yang membaca berita detik.com memiliki opini yang menyetujui pendapat Fraser Anning.

Maka, peneliti menyimpulkan bahwa ada 2 berita $(3,7 \%)$ yang menurut peneliti melanggar Pedoman Peliputan teror karena memuat pendapat yang mendukung legitimasi terhadap tindakan teror di Selandia Baru.

\section{Stigma Tidak Relevan}

Wartawan dalam menulis atau menyiarkan berita terorisme harus berhatihati agar tidak memberikan atribusi, gambaran, atau stigma yang tidak relevan. (Poin 5 Pedoman Peliputan Terorisme). Misalnya dengan menyebut agama yang dianut atau kelompok etnis si pelaku. Goffman (dalam Mubarok, 2012) membedakan stigma menjadi 3 jenis.

1. Abominations of the body (ketimpangan fisik). Jenis stigma ini diberikan kepada orang yang memiliki ciri khusus secara fisik yang berbeda dengan orang lain.

2. Blemishes of individual

Character. Merujuk pada orang yang mempunyai karakter individual tercela.

3. Tribal Stigma. Berkaitan dengan kesukuan termasuk didalamnya ras, agama, bangsa, wilayah, agama dan politik.

Dalam penelitian ini, peneliti tidak memukan adanya penjelasan ketimpangan fisik pelaku ataupun karakternya, peneliti menemukan ada penyebutan asal negara dan ras pelaku teror dalam 15 berita $(27,8$ $\%)$ detik.com yang diangkat di hari pertama terjadinya teror.

Tabel.4

Penyebutan asal Negara dan Ras Pelaku Teror

\begin{tabular}{|c|c|c|c|c|c|}
\hline & & Frequency & Percent & $\begin{array}{c}\text { Valid } \\
\text { Percent }\end{array}$ & $\begin{array}{c}\text { Cumulative } \\
\text { Percent }\end{array}$ \\
\hline \multirow[t]{3}{*}{ Valid } & Ada & 15 & 27,8 & 27,8 & 27,8 \\
\hline & Tidak Ada & 39 & 72,2 & 72,2 & 100,0 \\
\hline & Total & 54 & 100,0 & 100,0 & \\
\hline
\end{tabular}

menjelaskan bahwa pelaku adalah seorang pria Australia yang mengindentifikasikan dirinya sebagai pria "kulit putih" yang telah menulis manifesto berisi ideologi ekstrem kanan yang anti-Islam dan antiimigran:

Tabel. 5

Contoh penyebutan Asal Negara dan Ras 


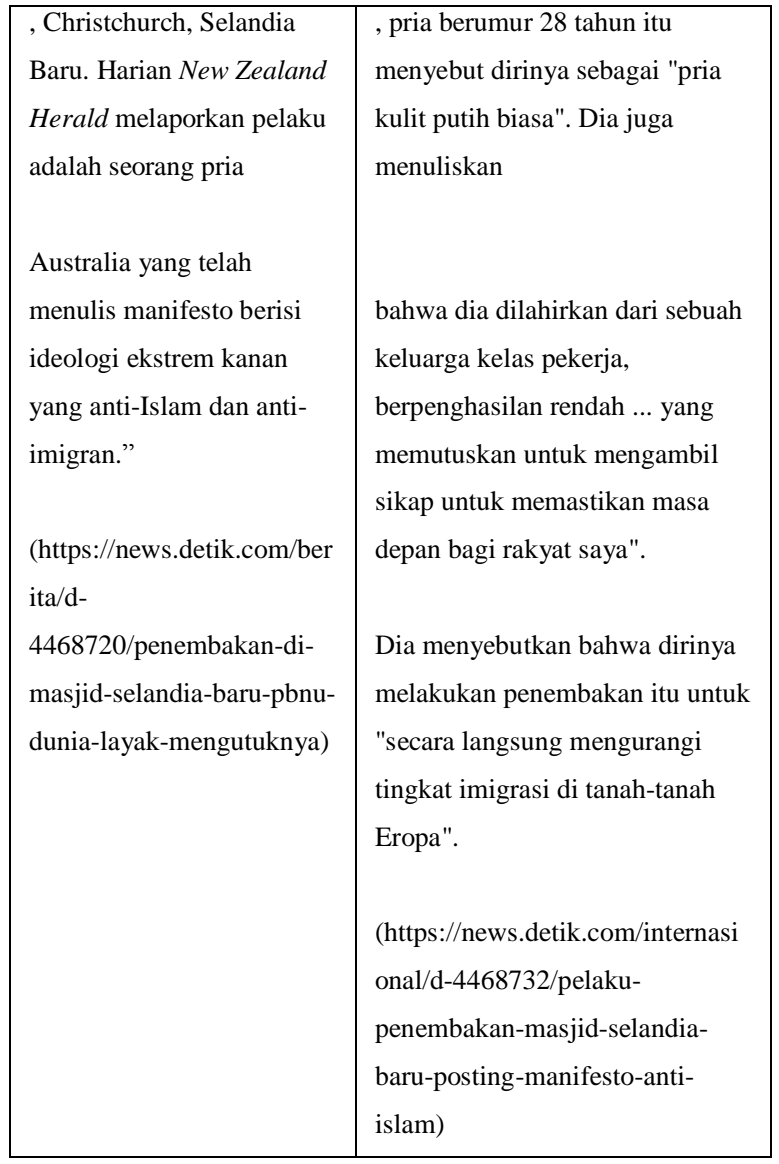

Penyebutan asal negara dan ras oleh detikcom dalam peristiwa teror di Selandia Baru memang merupakan bagian fakta. Namun menyebutkan Negara Australia yang dibarengi dengan pria kulit putih, anti imigran , anti islam dan keluarga kelas pekerja menjadi tidak relevan dijadikan pemberitaan karena justru hanya akan menguntungkan bagi pelaku guna menyebarkan ideologi anti islam, anti imigran yang ingin desebar luaskan oleh pelaku teror.

Tidak hanya itu. Kata kulit putih, anti imigran, dalam konteks Australia justru memiliki sejarah kelamnya sendiri. Dimana di tahun 1901 pemerintah

\begin{tabular}{|c|c|}
\hline Pria Australia & Pria Kulit Putih Biasa \\
\hline "Diberitakan sebelumnya, & Seperti dilansir \\
terjadi penembakan di & News.com.au, Jumat \\
Masjid Al Noor, & $(15 / 3 / 2019)$, \\
\hline
\end{tabular}

Australia pernah memberlakukan

kebijakan " Immigration Restriction Act atau dikenal dengan sebutan White Australia Policy sebuah kebijakan yang ingin membatasi imigran masuk ke Australia, terutama imigran-imigran kulit berwarna, kebijakan bernada rasis yang ingin menujukkan superioritas kulit putih dibanding dengan kulit berwarna. ${ }^{1}$

Menurut Sandy Rahmana Poetrie kebijakan White Australia Policy saat itu memiliki 2 maksud yang bernuansa rasis (Poetrie, 2013):

Pertama. Pemerintah berkeinginan agar keturunan eropa bisa tetap berkembang di wilayah Australia tanpa dirusak adanya pertumbuhan ras non eropa.

Kedua. Pemerintah percaya bahwa imigran kulit berwarna akan menyebabkan kurangnya lapangan pekerjaan bagi masyarakt golongan buruh kulit putih.

Kebijakan bernuansa rasis itu memang sudah tidak berlaku sejak 1973. Namun dampaknya masih sangat terasa di negeri kanguru tersebut. Masih ada

\footnotetext{
${ }^{1}$ Sandy Tieas Rahmana Poetri. Diskriminasi Imigran Kulit Putih Berwarna Dalam Masa Kebijakan Multikulturalisma Pasca Penghapusan White Australia Policy. Jurnal Kajian Sastra dan Budaya vol.1 no 2. hal 10.
} 
diskriminasi dalam seleksi partai politik, dan butuh waktu yang cukup lama agar imigran non kulit putih di panggung politik Australia. (kompas.com: 2010)

Dengan adanya fakta sejarah yang bernuansa rasis di Australia, menurut peneliti keterangan asal negara pelaku "Australia" yang dikaitkan dengan warna kulit pelaku "kulit putih" menjadi tidak relevan dalam pemberitaan teror, dan akan lebih baik jika di hindari, karena berpotensi negatif bagi khalayak. Beberapa potensi negatif yang mungkin muncul antara lain:

Pertama. Diangkatnya secara berulang ulang asal negara dan ras pelaku yang merupakan warga Australia dan pria kulit putih justru membuat media secara tidak langsung turut menyebarkan ideologi ekstrem pelaku teror. Ideologi rasis yang ingin menunjukkan superioritas kulit putih atas kulit berwarna, terutama imigran kulit berwarna.

Kedua. Dapat memunculkan adanya legitimasi atau pembenaran perilaku teror di selandia baru. Terutama bagi masyarakat yang mendukung ideologi rasis tersebut.

Ketiga. Melanjutkan spiral kebencian antara penduduk Australia dengan imigran yang berpotensi Keempat. Dapat memunculkan stigma bahwa pria kulit putih Australia adalah teroris. Karena itu, peneliti menyimpulkan penyebutan Asal Negara dan Ras pelaku pada $15(27,8 \%)$ berita detik.com di hari saat terjadinya teror merupakan tribal stigma dan termasuk ke dalam stigma yang tidak relavan.

\section{Preasumption of Innocent}

Wartawan harus selalu menyebutkan kata "terduga" terhadap orang yang ditangkap oleh aparat keamanan karena tidak semua orang yang ditangkap oleh aparat secara otomatis adalah pelaku tindak terorisme. (Poin 6 Pedoman Peliputan Terorisme)

Sayangnya dalam pemberitaan teror di Selandia Baru, terdapat $17(31,5 \%)$ berita detik.com yang tidak menggunakan kaidah preasumption of innocent yaitu tidak menggunakan kata terduga saat menyebutkan pelaku.

Berita yang tidak menggunakan kata terduga

\begin{tabular}{|c|c|c|c|c|c|}
\hline & & Frequency & Percent & $\begin{array}{c}\text { Valid } \\
\text { Percent }\end{array}$ & $\begin{array}{c}\text { Cumulative } \\
\text { Percent }\end{array}$ \\
\hline \multirow[t]{4}{*}{ Valid } & Ada & 17 & 31,5 & 31,5 & 31,5 \\
\hline & Tidak & 37 & 68,5 & 68,5 & \multirow{3}{*}{100,0} \\
\hline & Ada & & & & \\
\hline & Total & 54 & 100,0 & 100,0 & \\
\hline
\end{tabular}

Tabel.6

Penyebutan nama Brenton Tarrant, Pria Australia Penulis Manifesto, Pria Kulit 
Putih, 3 Pria dan 1 Wanita sebagai pelaku sama sekali tidak menyertakan kata "terduga" yang seharusnya digunakan media sebagai bentuk "Preasumption of

Innocent".

\section{Pelaku Bernama Brenton Tarrant}

Berita detik.com yang menyebut Brenton Tarran sebagai pelaku merupakan informasi yang

$\begin{array}{lrr}\text { dilansir } & \text { detik.com } & \begin{array}{c}\text { Gambar.3 } \\ \text { Berita menyebut } \\ \text { Brenton Tarrant }\end{array} \\ \text { dari New } & \text { Zealand } & \end{array}$

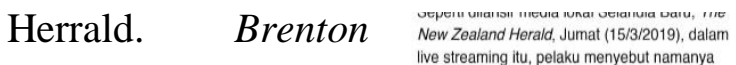

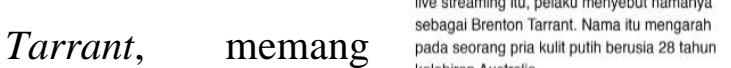
merupakan tokoh antagonis dalam aksi teror di Selandia Baru, namanya mencuat setelah akun media sosial facebook melakukan live streaming aksi teror. Munculnya nama Brenton Tarrant berasal dari pengakuannya sendiri di akun facebook tersebut.

Nama Brenton Tarrant juga dikaitkan detik.com dengan pria kulit putih berusia 28 tahun, kelahiran Australia, memiliki akun Facebook bernama 'brenton.tarrant.9.' dan akun Twitter bernama@brentontarrant. Akun media sosial tersebut diberitakan memposting foto senapan dan perlengkapan militer yang ditulisi nama-nama juga pesan terkait nasionalisme kulit putih yang juga memposting sebuah manifesto setebal 87 halaman yang dipenuhi pandangan antiimigran dan anti-muslim. Senapan yang diunggah di media sosial tersebut, merupakan senapan yang sama yang terlihat dalam siaran live streaming pelaku penembakan masjid di Christchurch.

\section{Orang Pelaku. 3 Pria dan 1 Wanita}

Dalam beberapa berita, detik.com menyebut bahwa pelaku penembakan berjumlah 4 orang

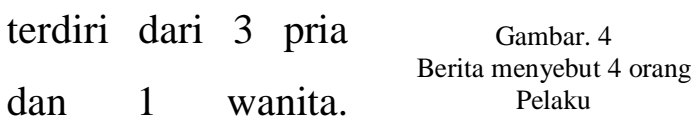

\begin{tabular}{|c|c|c|}
\hline $\begin{array}{l}\text { Keterangan } \\
\text { terdapat }\end{array}$ & ini & 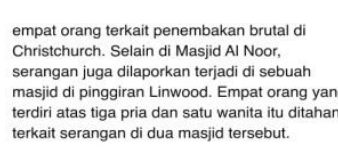 \\
\hline & & 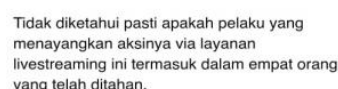 \\
\hline
\end{tabular}
menjelaskan bahwa ke empat orang pelaku tersebut sudah di tahan oleh Kepolisian Selandia Baru.

Penyebutan nama Brenton Tarrant dan 4 orang pelaku yang terdiri dari 3 Pria dan 1 Wanita sebagai pelaku oleh detik.com tidak disertai keterangan "terduga", padahal kata terduga dalam pemberitaan teror, merupakan kata penting yang menjadi bagian dari proses preassumption of innocent.

Bagaimanapun asas praduga tidak bersalah adalah bagian dari Hak Asasi Manusia. Mengacu kepada The Universal Declaration of Human Right pasal 11 dijelaskan bahwa setiap orang perlu untuk dianggap belum bersalah sampai terbukti bahwa benar ia bersalah menurut hukum dalam suatu peradilan terbuka tempat ia mendapat hak untuk pembelaanya. 
R.H Siregar seperti dikutip Prof. Loebby Loqman, SH (Jurnal Dewan Pers, 2010) menjelaskan ada beberapa cara yang dilakukan media massa dalam mengimplementasikan asas praduga tak bersalah pada pemberitaan. Diantaranya:

- Mereka yang mentaati asas praduga tidak bersalah dengan hanya menulis inisial pelaku saja, tanpa menyebut nama lengkap juga tidak memuat gambarnya.

- Mereka yang memuat identitas serta gambar seorang tersangka/terdakwa secara lengkap dalam pemberitaan media massa dengan kriteria tertentu. Misal, apabila perbuatan yang dilakukan pelaku sangat kejam dan melebihi batas kemanusiaan, maka media massa, tidak perlu lagi melindungi identitas tersangka/terdakwa.

- Mereka yang memilih menuliskan identitas pelaku, fokus pada pelaku, bukan pada kasusnya. Apabila pelakunya merupakan "public figure" atau "tokoh publik" maka, nama dan identitas pelaku akan ditulis lengkap dengan alasan bahwa melaku sudah menjadi milik publik, maka publik perlu tahu tindak perilakunya.

- Mereka yang memuat gambar pelaku namun menutup matanya, meskipun identitas dimuat secara lengkap atau sebaliknya.

Dari beberapa pendapat diatas peneliti menyimpulkan bahwa media massa sebaiknya tidak mengungkapkan identitas pelaku kecuali pada pemberitaan yang melebihi batas-batas kemanusiaan termasuk dalam hal ini tindakan teror. Jadi penyebutan identitas pelaku, dalam kasus terorisme diperbolehkan, hanya saja, merujuk pada kode etik pemberitaan terorisme, media massa harus menggunakan kata "terduga" dalam menyebut identitas orang yang diungkap.

Dengan demikian, maka, peneliti menyimpulkan bahwa pelanggaran asas praduga tidak bersalah dalam pemberitaan teror di detik.com yang muncul di hari pertama adalah pemberitaan yang menyebutkan nama pelaku "Brenton Tarrant" tanpa disertai kata terduga, yakni terdapat 9 berita $(16,7 \%)$. Adapun berita yang tidak menyebutkan nama, atau hanya menulis "4 Orang Pelaku, 3 Pria dan 1 Wanita" tidak termasuk kedalam pelanggaran asas praduga tak bersalah, karena tidak ada penyebutan nama. 
Tabel. 7

Pelanggara Asas Praduga Tak Bersalah

\begin{tabular}{|cc|c|c|c|c|}
\hline & & Frequency & Percent & $\begin{array}{c}\text { Valid } \\
\text { Percent }\end{array}$ & $\begin{array}{c}\text { Cumulative } \\
\text { Percent }\end{array}$ \\
\hline Valid & Ada & 9 & 16,7 & 16,7 & 16,7 \\
& Tidak Ada & 45 & 83,3 & 83,3 & 100,0 \\
& Total & 54 & 100,0 & 100,0 & \\
\hline
\end{tabular}

\section{Rincian Modus Operandi}

Wartawan wajib menghindari mengungkap rincian modus operandi tindak pidana terorisme seperti cara merakit bom, komposisi bahan bom, atau teknik memilih sasaran dan lokasi yang dapat memberi inspirasi dan memberi pengetahuan bagi para pelaku baru tindak terorisme. (Poin 7 Pedoman Peliputan Terorisme)

Pemberitaan tentang modus operandi suatu kejahatan menurut Prof. Loebby Loqman, SH (Jurnal Dewan Pers, 2010) dapat menjadi informasi agar masyarakat melakukan antisipasi, namun, di lain pihak modus operandi tersebut dapat ditiru oleh teroris lainnya.

Sayangnya, dalam pemberitaan detik.com, dari 54 berita kami menemukan ada $22(40,7 \%)$ berita detik.com yang menjelaskan rincian modus operandi.

Tabel.8

Rincian Modus Operandi

\begin{tabular}{|ll|r|r|r|r|}
\hline & Frequency & Percent & \multicolumn{1}{c|}{$\begin{array}{c}\text { Valid } \\
\text { Percent }\end{array}$} & $\begin{array}{c}\text { Cumulative } \\
\text { Percent }\end{array}$ \\
\hline Valid & Ada & 22 & 40,7 & 40,7 & 40,7 \\
& Tidak Ada & 32 & 59,3 & 59,3 & 100,0 \\
& Total & 54 & 100,0 & 100,0 & \\
\hline
\end{tabular}

Rincian modus operandi yang di beritakan detik.com antara lain tentang: Kronologi Penembakkan, Pelaku Melakukan Live Streaming di Facebook, dan Penemuan Bahan Peledak di Mobil Pelaku.

\section{Kronologi Penembakkan}

Ada 9 berita dari 54 berita detik yang menjelaskan kronologi penembakkan. Penjelasan tentang kronologi di dapatkan dari keterangan saksi yang berhasil selamat dari aksi penembakan. Dari 8 berita yang menceritakan tentang kronologi penembakkan tersebut, ada 2 berita yang menjelaskan kronologi dengan cukup lengkap .

Pertama: Berita detik.com tanggal hari Jumat, 15 Mar 2019 11:50 WIB, dalam berita yang berjudul "Penembakan Brutal di 2 Masjid Selandia Baru, 4 Orang Ditangkap". Mengutip sumber anonim berikut bagaimana detik.com $\begin{gathered}\text { menembak mereka. Saya mendengar salat } \\ \text { seorang perempuan menningagl dunia.". }\end{gathered}$ Gambar. 5 Kronologi Penembakkan

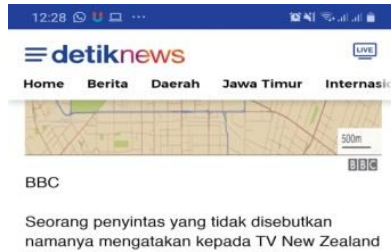
namanya mengatakan kepada TV New Zealan bahwa dia melihat pelaku bersenjata
menembak seorang pria pada bagian dada. Dia memperkirakan penembakan berlangsung selama 20 menit dan sedikitnya 60 orang mungkin cedera. Pelaku dilaporkan menyasar ruang salat bagian pria di masjid, kemudian beralih ke ruang perempuan.

"Yang saya lakukan pada dasarnya hanya menunggu dan berdoa, 'Ya Tuhan, saya moho agar orang ini kehabisan peluru'," papar saks "Dia datang ke bagian sini, dia menembak bagian sini. Dia lalu beranjak ke ruangan lair dan ke bagian perempuan kemudiaa menjelaskan kronologi penembakkan dengan cukup lengkap.

Kedua: Berita detik.com tanggal hari Jumat, 15 Mar 2019 15:15 WIB, dalam berita yang berjudul "Kesaksian Jamaah 
Masjid Al Noor Saat

Terjadi Penembakan".

Mengutip saksi

bernama Ahmad Al-

Mahmoud, detik.com

menceritakan

bagaimana pelaku

beraksi, mulai dari

waktu penembakkan,

pakaian yang

digunakan, cara

menembak, berapa kali jumlah tembakkan

hingga ruang apa saja yang di masuki.

\section{Pelaku Live Streaming di Facebook}

Rincian modus operandi selanjutnya tentang aksi pelaku yang menayangkan aksi brutalnya via layanan live streaming di Internet. Tidak hanya itu, dengan mengutip berita yang bersumber dari The New Zealand Herald konten tayangan live streaming diceritakan detik.com dengan sangat detil:

Gambar.7

Berita dengan detil live streaming

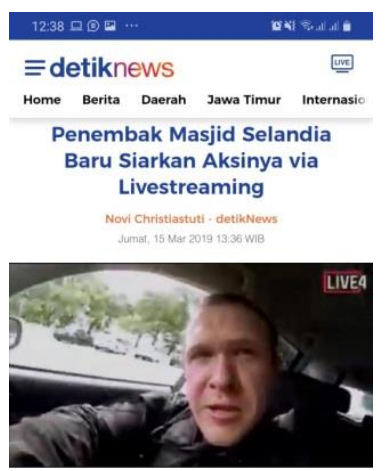

$\equiv$ detiknews

Home Berita Daerah Jawa Timur Internasio

Seperti dilansir media lokal Selandia Baru, The New Zealand Herald, Jumat (15/3/2019), dalam ive streaming itu, pelaku menyebut namanya sebagai Brenton Tarrant. Nama itu mengarah pada seorang pria kulit putih berusia 28 tahun kelahiran Australia.

Tayangan livestream itu dimulai dengan pelaku mengemudikan mobilnya ke Masjid AI Noor d Deans Ave, Chistchuch. Pelahu kemudan tenhal memarkinkan mobinya di deka jalan Pellow eju, sebu the Now Zealand Horald, beris cilan senja api dan amunisiyang

Adegan selanjutnya menunjukkan aksi brutal yang dilakukan pelaku. Pelaku tampak mempersenjatai diri dan berjalan ke dalam masjid, dengan korban pertama ditembak $d$ dekat pintu. Dalam aksinya ini, pelaku menggunakan setidaknya satu pucuk senapan semi-otomatis dan banyak amunisi. sebuah masild di Christchurch, Selandia $B$ sempat menayangkan aksi brutalnya via streaming berdurasi 17 mernet. Video live

Seperti dilansir media lokal Selandia Baru, The New Zealand Herald, Jumat (15/3/2019), dalam

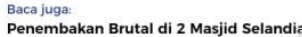

Dari 12 berita yang menyertakan keterangan bahwa pelaku penembakkan melakukan live streaming di internet, peneliti hanya menemukan 1 berita (berita diatas) yang menjelaskan konten secara detil. Sedangkan 11 sisanya hanya menyertakan live streaming sebagai keterangan tambahan yang menjadi pelengkap berita.

\section{Penemuan Bahan Peledak}

Rincian modus operandi selanjutnya

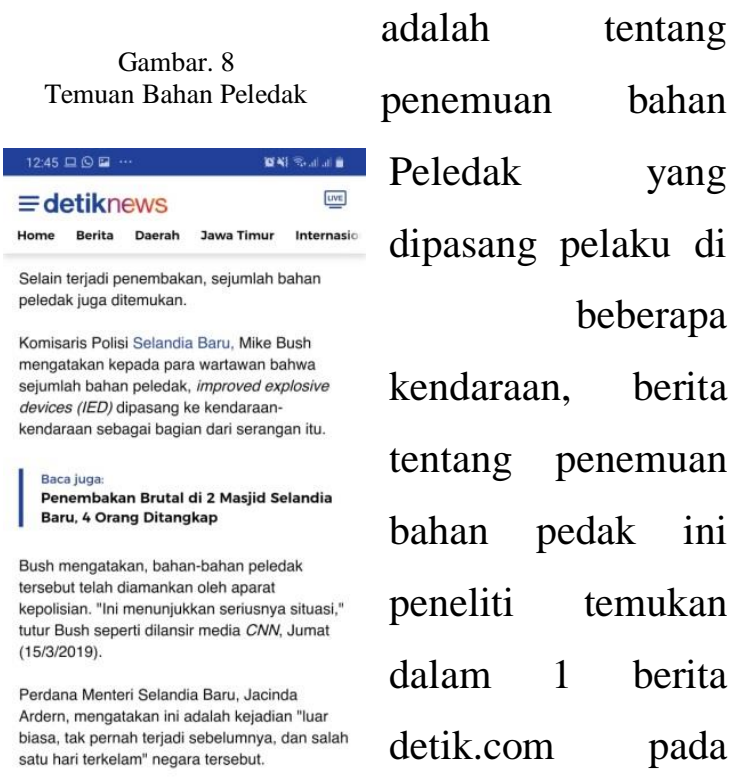
yang berjudul "Penembakan Brutal di Masjid Selandia Baru, Ditemukan Bahan Peledak". Melansir berita dari CNN detik.com menjelaskan jenis bahan peledak dan di mana peledak tersebut di pasang.

Dari 22 berita yang berisi rincian modus operandi, memang hanya ada 4 berita yang menurut peneliti secara detil menjelaskan rincian modus operandi, 
diantaranya; 2 berita tentang menjelaskan detil tentang kronologi penembakkan, 1 berita menjelaskan detil tentang live streaming serta konten di dalamnya dan 1 berita menjelskan detil tentang penemuan bahan peledak yang menjelaskan jenis, dan dimana bahan peledak di pasangkan.

Namun meski sedikit secara kuantitas, dengan adanya berita yang detil tentang rincian modus operandi yang diangkat oleh detik.com pada hari terjadinya teror, tentu saja khalayak bisa mengetahui, bagaimana pelaku melaksanakan aksi teror nya; mulai dari seragam yang digunakan, kedatangan, peristiwa penembakan, ruangan apa saja yang di masuki, hingga senjata apa saja yang digunakan pelaku dan di mana senjata tersebut di pasangkan.

Penjelasan mendetil seperti dalam 4 berita detik.com tadi, tentu cukup untuk dapat memberi inspirasi dan memberi pengetahuan bagi para pelaku baru tindak terorisme. Karena itu, peneliti menyimpulkan ada pelanggaran Pedoman Peliputan Terorisme yang dilakukan oleh detik.com dalam konteks menjelaskan modus operandi.

\section{Menampilkan Foto atau Video Korban}

Wartawan tidak menyiarkan foto atau adegan korban terorisme yang berpotensi menimbulkan kengerian dan pengalaman traumatik. Pemuatan foto atau adegan hanya diperbolehkan bila bertujuan untuk menyampaikan pesan kemanusiaan bahwa terorisme selalu menyasar sasaran umum dan menelan korban jiwa. (Poin 8 Pedoman Peliputan Terorisme).

Terdapat 8 berita $(14,8 \%)$ detik.com yang memuat foto korban.

\begin{tabular}{|} 
Tabel.8 \\
\multicolumn{1}{|c|}{$\begin{array}{c}\text { Foto Korban } \\
\end{array}$} & Frequency & Percent & $\begin{array}{c}\text { Valid } \\
\text { Percent }\end{array}$ & $\begin{array}{c}\text { Cumulative } \\
\text { Percent }\end{array}$ \\
\hline Valid & Ada & 8 & 14,8 & 14,8 & 14,8 \\
& Tidak Ada & 46 & 85,2 & 85,2 & 100,0 \\
& Total & 54 & 100,0 & 100,0 & \\
\hline
\end{tabular}

Adapun foto-foto korban yang ditampilkan oleh detik.com adalah foto yang menampilkan kondisi korban yang sedang di tandu menuju ambulance. Lalu, apakah dengan foto-foto tersebut berpotensi
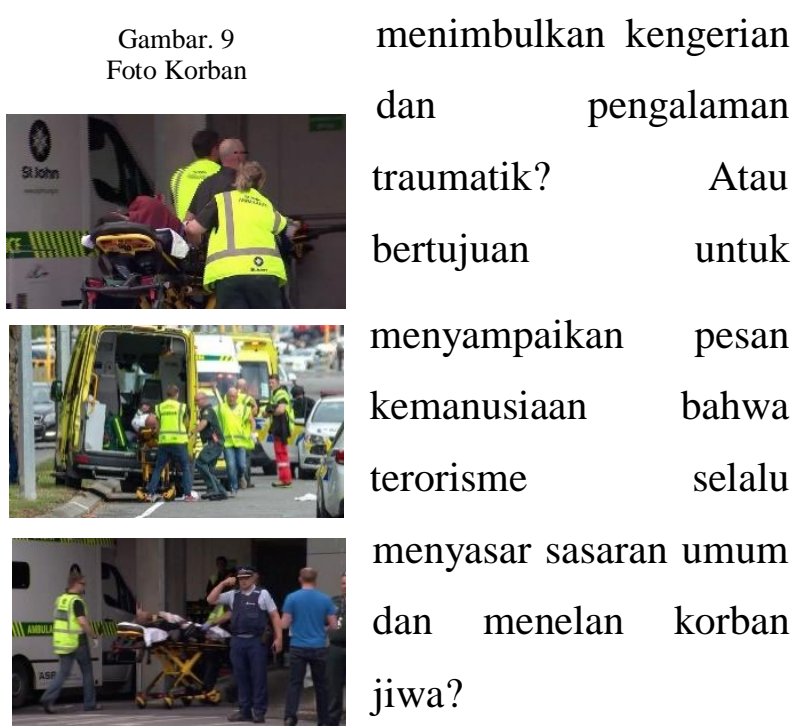

Dari 8 berita yang memuat foto korban, sebenarnya hanya ada 3 jenis foto 
yang ditampilkan detik.com dalam pembertitaannya. (Perhatikan Gambar 9)

Dari ketiga foto tersebut, tidak ada satu pun yang menurut peneliti menimbulkan kengerian dan traumatik.

Setidaknya, tidak ada foto yang menampilkan, korban meninggal, bersimbah darah atau menunjukkan luka tembakan yang tidak diperbolehkan untuk ditunjukkan kepada khalayak seperti yang dilarang dalam kode etik jurnalistik.

Dengan demikian dapat disimpulkan bahwa foto yang ditampilkan oleh detik.com masih sesuai dengan kode etik jurnalistik dan sesuai dengan Pedoman Peliputan Terorisme yang dikeluarkan oleh dewan pers.

\section{Proses Check dan Recheck}

Wartawan wajib selalu melakukan check dan recheck terhadap semua berita tentang rencana maupun tindakan dan aksi terorisme ataupun penanganan aparat hukum terhadap jaringan terorisme untuk mengetahui apakah berita yang ada hanya sebuah isu atau hanya sebuah balon isu (hoax) yang sengaja dibuat untuk menciptakan kecemasan dan kepanikan. (Poin 13 Pedoman Peliputan Terorisme)

Proses check dan recheck dalam jurnalistik merupakan hal sangat penting dan sangat mendasar apalagi berkaitan dengan peristiwa besar seperti tindakan terorisme. Andai memberitakan hoax, maka ada kemungkinan jurnalis turut menciptakan teror bagi khalayak.

Tabel.8

Check dan Recheck

\begin{tabular}{|ll|r|r|r|r|}
\hline & & & Valid \\
& Frequency & Percent & Percent & $\begin{array}{c}\text { Cumulative } \\
\text { Percent }\end{array}$ \\
\hline Valid & Ada & 43 & 79,6 & 79,6 & 79,6 \\
& Tidak Ada & 11 & 20,4 & 20,4 & 100,0 \\
& Total & 54 & 100,0 & 100,0 & \\
\hline
\end{tabular}

Dari 54 berita yang kami uji, 43 $(79,6 \%)$ berita tercatat melakukan proses check dan recheck. Meski banyak berita yang melansir dan berasal dari media asing, berita-berita yang detik.com lansir dan kutip memiliki proses check dan recheck yang baik kepada narasumber utama yang memang berkompeten untuk menceritakan kejadian teror tersebut. Begitu juga dengan berita yang berasal dari detik.com sumber berita terkait dengan korban WNI di Selandia Baru, langsung berasal dari KBRI ataupun keluarga korban langsung bukan sumber anonim yang berpotensi dipertanyakan kredibilitasnya. Perhatikan 3 berita berikut ini: Gambar. 10

Berita dengan proses Check dan Recheck

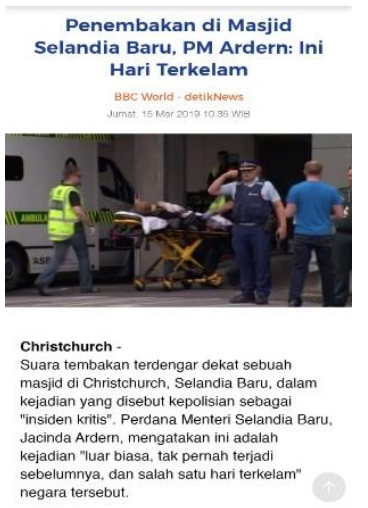

Padang - Dua warga negara Indonesia menjad korban penembakan brutal di masjid di Selandi merupakan warga Sumatera Barat. Kedua korban ini adalah Zulfirmansyah dan Mohammad Rais, yang merupakan ayah dan Hendra Yaspita, kakak kandung kortan di Kot Padang, melalui pesan singkatnya
membenarkan hal tersebut. Pihak keluarga, kata Hendra, mendapat kabar tentang apa yan menimpa adiknya itu melalui istri korban. Baca juga:
MUI Minta Muslim di RI Jaga Kondusifitas
Paca Sag

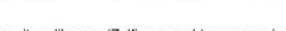
"lyar, kon. Dia adik kandung saya paling terakhir dari enam bersaudara. Dapat kabar dari isti beliau," kata Hendra kepada wartawan. 
Adapun berita yang menurut peneliti terlihat seperti tidak melakukan proses check dan recheck dalam beritanya antara lain: 2 berita dengan sumber anonim dan 9 berita teror yang mengutip media sosial.

Pertama. Berita dengan Sumber Anonim. Berita pertama yang diangkat merupakan laporan awal tentang terjadinya Teror di Selandia Baru. Proses pemberitaan jenis ini memang biasa dilakukan detik.com, dengan prinsip "Mengapa harus menunggu besok? Detik ini juga!" yang dipegang erat detik.com persitiwa besar seperti terorisme pasti akan segera di angkat.

Sayangnya, dalam berita pertama ini, detik.com mengutip berita dari ABC Australia yang belum menyebutkan nama saksi mata atau sumber anonim. Idealnya sebuah berita mengutip nara sumber yang jelas dan disebutkan namanya, bukan sumber anonim.

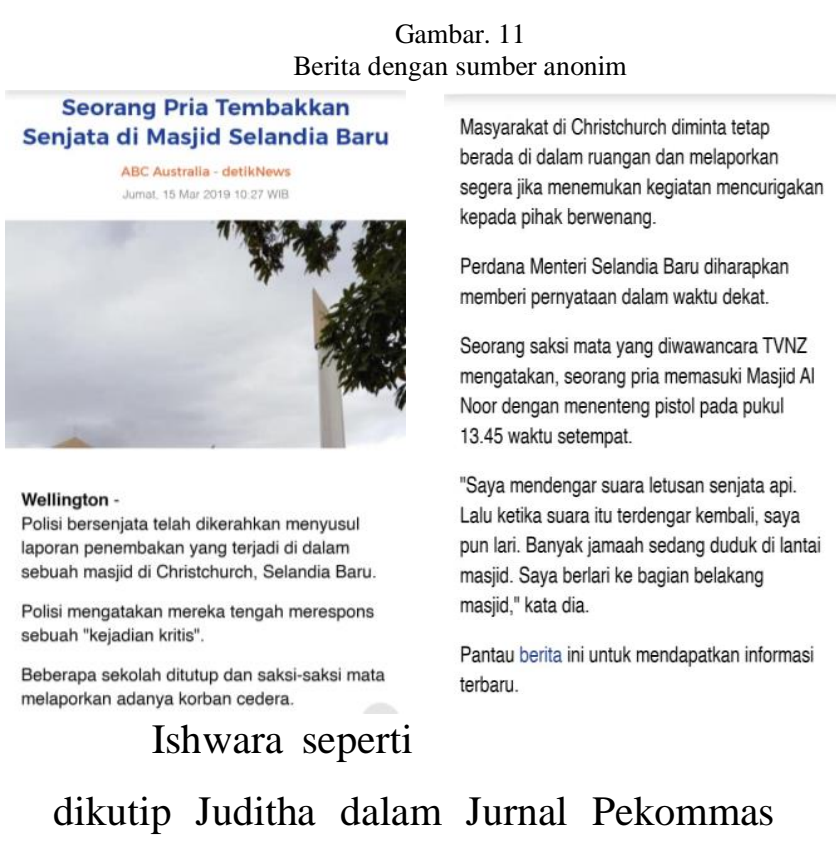

(2013:150) menjelaskan bahwa mutu suatu tulisan ditentukan oleh seberapa jelas sumbernya dan apa keahliannya, karenanya nama sumber berita harus dituliskan dengan jelas. Ini merupakan bagian dari tanggung jawab jurnalis dan media massa.

Berita pertama yang diunggah detik.com tentang peristiwa teror di selandia baru merupakan implementasi dari visi detik.com untuk menjadi media penyedia informasi tercepat, berita sejenis running news seperti ini lazim terjadi di detik.com. Karena itu, di akhir berita pertama terlihat detik.com meminta pembaca untuk memantau berita tersebut untuk mendapatkan informasi terbaru. Adapun berita-berita detik.com selanjutnya dilengkapi dengan sumber informasi yang jelas dan kredibel.

Berita selanjutnya yang menggunakan sumber anonim adalah berita tentang Gambar. 12 Berita tentang travel advice
advicecheck travel advice ke Selandia Baru oleh

\begin{tabular}{|c|c|}
\hline detiktravel & . LIVETV \\
\hline
\end{tabular}
Dirangkum detikcom dari berbagai sumber, Jumat $(15 / 3 / 2019)$ pasca penembakan dua negara yaitu $\begin{aligned} & \text { tersebut, Inggris dan AS mengeluarkan Travel } \\ & \text { Advice ke Selandia Baru. Travel Advice adalah }\end{aligned}$ suatu imbauan yang diberikan negara pada AS dan Inggris.

Dalam beritanya "Warga negara Inggris di daerah tersebut disarankan untuk tetap waspada dan mengiku
arahan dari otoritas setempat," tulis Travel detik.com hanya menyebutkan bahwa informasi Advice Inggris.

Sedangkan pemerintah AS, meminta warganya juga hati-hati dan mengikuti perkembangan terkini di berbagai media pemberitaan dan media sosial. Serta, diminta untuk selalu tersebut dirangkum dari berbagai sumber, tanpa menjelaskan sumber aslinya ataupun 
dokumen yang berkaitan dengan travel advide yang dimaksud.

Kedua. Berkaitan tentang kutipan detik.com terhadap media sosial tokoh. Media social tokoh yang dikutip tidak ditampilkan, dan tidak meminta konfirmasi kepada pemilik media social apakah media sosial yang dikutip, benar miliknya, atau apakah konten media sosial yang dikutip memang merupakan konten yang ditulis dan diupload oleh pemilik akun.

Praktek ketiadaan check dan recheck terhadap akun media sosial ini pernah terjadi yang berakibat pada beredarnya isu hoax atau misinformasi. Contohnya Kisah Imanda Amalia yang sempat dikabarkan tewas saat tengah terjadi gejolak politik di Mesir tahun 2011. Informasi tentang tewasnya Imanda pertama kali disebarkan dilaman grup Facebook, Science of Universe. Berita ini juga diperkuat dengan akun yang mengaku teman Imanda bernama Pummy Kusuma yang menjelaskan bahwa mereka terjebak dalam baku tembak dan memohon do'a. Laman itu bahkan memuat foto perempuan berjilbab putih yang disebut-sebut sebagai Imanda dan kemudian dipampang sejumlah media online.

Faktanya, informasi tersebut hanyalah hoax belaka, sebuah informasi tanpa dasar yang akhirnya juga di klarifikasi di dalam grup facebook tersebut. Tidak jelas siapa itu Imanda, adapun foto yang disebar ternyata milik seorang perempuan bernama Farina, bukan Imanda. Foto Farina yang dicuri dari laman web dan dipajang di laman Facebook Science of Universe. Sayangnya berita tersebut sudah terlanjur menghiasi banyak media online.

Kisah Imanda merupakan bukti bahwa disiplin verifikasi dan ketiadaan check dan recheck merupakan hal yang rawan dalam proses jurnalistik. Verifikasi yang tidak jalan akan berpotensi pada munculnya berita yang hoax yang disebar di media massa. Verifikasi harus diutamakan bukan malah ditinggalkan demi kecepatan.

Begitu juga, dengan berita yang dikutip detik.com dari media sosial. Meski hingga penelitian ini ditulis tidak ada penyangkalan ataupun protes dari namanama yang dikutip detik.com. Pengutipan pernyataan dari media sosial oleh detik.com baiknya diunggah akun media sosial dan pastikan akun tersebut sudah verified oleh situs penyedia, karena akun yang sudah verified merupakan keberadaan autentik dari tokoh publik, selebriti, atau merek global yang diwakilinya. Atau, meskipun belum verified harus dipastikan untuk melakukan verifikasi langsung ke tokoh yang bersangkutan.

Karena itu, peneliti menyimpulkan terdapat terdapat 11 berita detik.com $(20,4$ 
$\%)$ di posting di hari pertama terjadinya teror yang terlihat tidak melakukan proses check dan recheck terhadap sumber berita.

\section{Narasumber tidak Relevan}

Wartawan dalam memilih pengamat sebagai narasumber wajib selalu memperhatikan kredibilitas, kapabilitas dan kompetensi terkait latar belakang, pengetahuan, dan pengalaman narasumber yang relevan dengan hal-hal yang akan memperjelas dan memberikan gambaran yang utuh terhadap fakta yang diberitakan.

(Poin 11 Pedoman Peliputan Terorisme)

Dari 54 berita, narasumber yang menjadi sumber berita detik.com sebenarnya memiliki kesesuaian dengan tema yang diangkat. Berita detik.com di hari pertama terjadinya teror di Selandia Baru baik yang merupakan liputan wartawannya ataupun yang melansir dan mengutip media luar negeri mayoritas memiliki nara sumber yang kredibel dan berwenang menyatakan pendapat, seperti: Perdana Menteri Selandia Baru, Kepolisian Setempat, Dubes RI, dan Humas Kominfo, Saksi Mata, Senator Australia. Pemimpin Dunia, Komunitas Muslim Australia, Politisi, dan Akun Media Sosial Tokoh. Pengutipan terhadap narasumber tersebut, memiliki kesesuaian dengan tema yang diangkat detik.com.

Hanya saja, 9 narasumber yang dikutip dari akun media sosial tidak disertakan sumber aslinya (seperti yang sudah di bahas di proses check dan recheck) dan tidak disertakan konfirmasi terhadap pemilik akun. Sumber seperti ini diragukan kredibilitasnya, apakah post tersebut merupakan tulisan asli narasumber yang dimaksud atau bukan. Selanjutnya terdapat 2 berita yang menggunakan sumber anonim yang juga dapat mengurangi kredibilitas sumber. Karena itu sumber seperti ini peneliti kategorikan ke narasumber yang tidak relevan, karena diragukan kredibilitas dan kredibilitasnya.

Tabel. 9

Nara Sumber Tidak Relevan

\begin{tabular}{|ll|r|r|r|r|}
\hline & & Frequency & Percent & $\begin{array}{c}\text { Valid } \\
\text { Percent }\end{array}$ & $\begin{array}{c}\text { Cumulative } \\
\text { Percent }\end{array}$ \\
\hline Valid & Ada & 11 & 20,4 & 20,4 & 20,4 \\
& Tidak Ada & 43 & 79,6 & 79,6 & 100,0 \\
& Total & 54 & 100,0 & 100,0 & \\
\hline
\end{tabular}

Maka, peneliti menyimpulkan bahwa dihari pertama terjadinya teror terdapat $11(20,4 \%)$ berita detik.com yang menggunakan narasumber yang tidak relevan.

Dengan demikian, dari hasil analisis terjadap 54 berita di media onlie detik.com yang dinaikkan di hari terjadinya teror. Peneliti menemukan temuan-temuan sebagai berikut: Mayoritas berita detik.com di hari pertama terjadinya teror bersumber dari media asing $(42,6 \%)$ baik mengutip ataupun melansir. Ini wajar, 
karena peristiwa teror memang terjadi di luar negeri. Adapun Media Asing yang dikutip oleh detik.com antara lain. ABC Australia, AFP, BBC World, Channel News Asia, CNN, news.com.au, Reuteurs, Stuff.Co.Nz, Telegraph, dan New Zealand Herald. Sedangkan sisanya berita detik.com berasal dari Keterangan Juru Bicara $(7,4)$, Keterangan Pers $(16,7)$ dan Liputan wartawan surat kabar $(33,3)$.

Peneliti menemukan adanya berita yang melanggar Pedoman Peliputan Teror. Diantaranya adalah: 2 berita $(3,7 \%)$ yang menunjukkan bentuk legitimasi terhadap tindakan teror di Selandia Baru. 15 berita $(27,8 \%)$ berita detik.com termasuk ke dalam stigma yang tidak relavan. 9 berita $(16,7 \%)$ masuk kedalam kategori melanggar preassumption of innocent. 54 berita $22(40,7 \%)$ menjelaskan rincian modus operandi. 11 berita detik.com (20,4 $\%$ ) di posting di hari pertama terjadinya teror yang terlihat tidak melakukan proses check dan recheck terhadap sumber berita. Dan $11(20,4 \%)$ berita detik.com yang menggunakan narasumber yang tidak relevan.

Dari berita-berita yang melanggar Pedoman Peliputan Teror tersebut, ada 3 kategori yang menurut peneliti berpotensi menjadikan detik.com sebagai media yang turut menyebarkan teror, diantarnya pelanggaran pada kategori pemberian legitimasi. Kategori stigma tidak relevan, dan kategori rincian modus operandi. Ketiga kategori tersebut mendukung keinginan terorisme untuk: Mendapatkan perhatian dengan diberitakannya rincian modus operandi. Mendapatkan pengakuan, rasa hormat dan legitimasi yang diwakilkan oleh cuitan Fraser Aning. Menyebar propaganda dan memberikan rasa takut kepada khalayak yang didapatkan dari seluruh berita yang mengandung 3 kategori tersebut (berita yang memuat rincian modus operandi, pemberian legitimasi dan berita yang memuat stigma tidak relevan).

\section{KESIMPULAN}

Berdasarkan hasil temua yang sudah dibahas di atas, peneliti menyimpulkan bahwa detik.com sebagai media online secara keseluruhan patuh terhadap Pedoman Pemberitaan Terorisme Dewan Pers karena tingkat pelanggarannya bernilai dibawah lima puluh persen.

Ini terlihat dari hasil kuantitatif 7 kategorisasi Pedoman Peliputan Teror, dari 54 berita yang dikaji dalam kategori: Promosi dan legitimasi terhadap tindakan terorisme, Memberikan atribusi, gambaran atau stigma yang tidak relevan, Asas Praduga tidak Bersalah, Mengungkap rincian modus Operandi Tindak Pidana Terorisme, Menyiarkan Foto atau Adegan Korban Terorisme, Memilih Pengamat yang memiliki kredibilitas, kabapiitas dan 
kompetensi, Melakukan Check dan Recheck.

Hasil ini juga sekaligus memberikan rekomendasi kepada portal berita detikcom untuk terus konsisten menjaga akurasi agar isi beritanya sesuai dengan Pedoman Peliputan Teror dan tidak menjadi corong dalam menyebarkan ketakutan. Kedepan, Detik.com juga diharapkan lebih meminimalisir terjadinya adanya berita yang berpotensi menjadi media penyalur teror.

\section{Daftar Pustaka}

Eriyanto.2013. Analisis Isi: Pengantar

Metodologi untuk Penelitian Ilmu

Komunikasi dan Ilmu-Ilmu Sosial

Lainnya. .Jakarta, Prenada Media

Group.

https://www.alexa.com/topsites/countries/I

D diakses pada 25 November 2019

James C. Foust. 2005. Online Journalism.

Principles and Practices of News or

The Web. Holcomb: Hathaway

Publisher.

Jordan, Ray. 2017. Ada Ledakan di

Terminal Kampung Melayu, Warga

Panik. diambil dari

https://news.detik.com diakses 1

November 2019

Juditha, Cristiany. 2013. Akurasi Berita

dalam Jurnalisme Online. Makassar:

Jurnal Perkommas, 16, (3).
Kompas.com. Kulit Putih Kuasai Politik

Australia. diambil dari

https://internasional.kompas.com

diakses pada tanggal 10 Desember 2019

Loqman, Loebby. 2010. Asas Praduga Tak Bersalah dalam Pemberitaan oleh Media Massa, Jurnal Dewan Pers 2, (6).

Margianto, J Heru. Syaefullah, Asep. Media Online: Pembaca, Laba, dan Etika Problematika Praktik Jurnalisme Online di Indonesia. Jakarta Pusat: Aliansi Jurnalis Independen (AJI) Indonesia.

Mubarok, M. 2012. Stigmatisasi

Pemberitaan Terorisme di Media

Massa. Interaksi: Jurnal Ilmu

Komunikasi 1, (1).

Peraturan Dewan Pers Nomor : 01/Peraturan-DP/IV/2015 Tentang Pedoman Peliputan Terorisme

Poetri, Sandi Ties Rahmana. 2013.

Diskriminasi Imigran Kulit Putih

Berwarna dalam masa Kebijakan

Multikulturalisme Pasca

Penghapusan White Australia Policy. Jawa Timur: Jurnal Kajian Sastra dan Budaya 1, (2).

Prajarto, Nunung. 2004. Terorisme dan Media Massa: Debat Keterlibatan Media. Jurnal Ilmu Sosial dan Ilmu Politik, 8 (1). 
Ramadan, Bilal. 2016. KPI Tegur 7

Televisi dan 1 Radio Soal

Penayangan Aksi Teror di Sarinah

diambil dari

https://www.republika.co.id, diakses

1 November 2019

Soriano, Manuel R. Torres. 2008.

Terrorisme and The Mass Media

after Al Qaeda: A Change of

Course?. Athena Intelligence

Journal, 3 (2).

Tim Redaksi. 2017. Bagaimana detikcom

Sangat Cepat Memberitakan Bom

Kampung Melayu, diambil dari

https://news.detik.com diakses 10

Oktober 2019.

Ward, Mike. 2002. Jurnalism Online.

Woburn: Focal Press. 